\title{
EVALUASI EFEKTIFITAS PENILAIAN KINERJA APLIKASI DSS PADA KOPERASI SIMPAN PINJAM KELING KUMANG
}

\author{
Arief Dwi Hartadi; Oktalia Juwita \\ Information Systems Department, School of Information Systems, Binus University \\ Jl. K.H. Syahdan No. 9, Palmerah, Jakarta Barat 11480 \\ ariefdwihartadi@gmail.com; oktalia.juwita@gmail.com
}

\begin{abstract}
Credit union has a substantial role in supporting the growth of the national economy. A number of credit Unions implements DSS application to promote and accelerate the process of decision-making by management. DSS can provide ease of calculation, accuracy in the calculation and examination. However, an IT investment in DSS application, as well as other investments, is a segment that depletes costs and effort. The cost is calculated from the procurement, and continues during maintenance or during the investment implemented. Thus the implementation of DSS on a credit union needs to be measured whether it is quite fit and gives positive impacts on decision-making by management and on sale.
\end{abstract}

Keywords: DSS, credit cooperatives, investment, management, sales

\begin{abstract}
ABSTRAK
Koperasi Simpan Pinjam mempunyai peran yang cukup besar dalam mendukung pertumbuhan ekonomi nasional. Penerapan DSS juga menjangkau Koperasi Simpan Pinjam untuk memajukan dan mempercepat suatu proses pembuatan keputusan oleh manajemen. DSS dapat memberikan kemudahan dalam melakukan perhitungan, ketelitian dalam perhitungan dan pemeriksaan. Namun, investasi TI dalam aplikasi DSS, sebagaimana investasi lainnya, merupakan segmen yang menguras biaya dan tenaga. Biaya tidak hanya dihitung mulai dari pengadaan, tetapi terus berlanjut selama pemeliharaan atau selama investasi itu dipergunakan. Maka dari itu implementasi DSS pada Koperasi Simpan Pinjam perlu diukur apakah cukup sesuai dan berdampak pada pengambilan keputusan oleh manajemen serta pada penjualan.
\end{abstract}

Kata kunci: DSS, koperasi simpan pinjam, investasi TI, manajemen, penjualan 


\section{PENDAHULUAN}

Koperasi Simpan Pinjam merupakan kegiatan usaha dominan yang dimiliki oleh bangsa ini. Keberadaan Koperasi mempunyai peran yang cukup besar dalam mendukung pertumbuhan ekonomi nasional. Seperti yang telah diketahui,pada kondisi krisis yang pernah dialami oleh bangsa ini, ketika begitu banyak perusahaan-perusahaan besar yang tumbang dan melakukan PHK dalam jumlah besar,bisnis Koperasi dengan fleksibilitasnya mampu bertahan dengan kondisi tersebut. Oleh karena itu, perlu diberikan suatu perhatian khusus terhadap pengembangan Koperasi.

Terlepas dari fleksibilitas Koperasi dalam menghadapi krisis ekonomi, terdapat beberapa permasalahan yang seringkali muncul pada Koperasi simpan pinjam terutama pada sektor informasi yang tersedia untuk pengambilan keputusan pada manajemen. Permasalahan-permasalahan yang sering muncul pada Koperasi Simpan Pinjam adalah antara lain Informasi Koperasiyang terbatas dan tidak detail, kualitas sumber daya yang dimiliki kurang memadai, kualitas pelayanan yang masih tergolong rendah,serta kurangnya sarana penunjang informasi dan akses pemasaran ke pasar yang potensial. Mengetahui hal itu, maka diperlukan suatu sistem yang dapat mendukung untuk mengatasi permasalahan-permasalahan yang timbul tersebut.

Salah satu upaya yang dapat diusung dan dikembangkan adalah dengan menyusun Pedoman Pengambilan Keputusan Pengembangan Investasi Koperasi Simpan Pinjam Berbasis Teknologi dan Sistem Informasi (Decision Support System/DSS) yang menjembatani permasalahan dasar Koperasi Simpan Pinjam dan kebutuhan pihak intermediary swasta untuk meningkatkan portofolio investasinya. DSS adalah sebuah kelas sistem informasi yang terkomputerisasi yang dapat mendukung keputusan. DSS dapat memberikan kemudahan dalam melakukan perhitungan, ketelitian dalam perhitungan dan pemeriksaan. Mengintegrasikan konsep DSS dan konsep kelayakan ekonomi dan finansial untuk pengembangan usaha Koperasi Simpan Pinjam diharapkan dapat memberikan efektivitas, efesiensi dan ketelitian bagi pihak pemerintah, pelaku usaha dan lembaga intermediary dalam melakukan pengambilan keputusan untuk mengembangkan Koperasi Simpan Pinjam.

Beberapa aplikasi DSS telah banyak dikembangkan untuk meningkatkan kinerja dari perusahaan. Aplikasi-aplikasi DSS yang dikembangkan tersebut adalah untuk membantu pengambilan keputusan yang tepat dalam proses informasi sehingga didapatkan hasil yang dapat memenuhi target dari perusahaan itu sendiri. Tetapi apakah aplikasi tersebut sudah sesuai dengan investasi yang sudah dikeluarkan dari pihak manajemen.Kelayakan sebuah proyek DSS yang memakan biaya cukup besar, apakah keberadaaannya cukup sesuai dan berdampak pada Manajemen? Maka dari itu, tujuan dari dilakukannya penelitian ini adalah sebagai berikut: (1) menganalisis Kelayakan aplikasi DSS apakah mampu dan mendukung pengambilan keputusan pada manajemen; (2) menganalisis cara kerja dari aplikasi DSS yang telah diterapkan dengan Analisis Generic IS/IT Values.

\section{METODE}

Penelitian dilakukan pada KOPERASI Keling Kumang di mana jangkauannya adalah untuk daerah Kalimantan Barat. Penelitian ini mengukur nilai TI dan dampak investasi dari DSS yang sudah digunakan pada koperasi tersebut dengan metode Information economics.

\section{Pengukuran Evaluasi Kelayakan Aplikasi}

Salah satu metode untuk melakukan penilaian terhadap kelayakan proyek adalah Information Economics (IE), yang dikembangkan oleh Parker (1988) untuk menghubungkan kinerja bisnis dengan 
teknologi informasi. Pada model ini, manfaat ditentukan melalui kombinasi dari analisis enhanced ROI, penilaian bidang bisnis, dan penilaian bidang teknologi.

Parker menglasifikasikan manfaat SI/TI ke dalam tiga bagian (Parker, 1988) yaitu: (1) tangible benefit - manfaat nyata atau yang berpengaruh secara langsung terhadap keuntungan instansi. Contohnya meningkatkan produktivitas, mengurangi penggunaan kertas, dan sebagainya. Analisis terhadap tangible benefit atau yang bersifat kuantitatif menggunakan perhitungan dengan metode simple ROI - Traditional Cost-Benefit Analysis (TCBA); (2) quasi benefit - manfaat yang berada di ruang "abu-abu”, atau yang berpengaruh langsung terhadap keuntungan tetapi susah dihitung ataupun sebaliknya, tidak berpengaruh secara langsung terhadap keuntungan tetapi dapat dihitung. Contohnya memperbaiki proses perencanaan, perbaikan pengambilan keputusan, dan sebagainya. Analisis terhadap quasi benefit menggunakan perhitungan sbb: value acceleration (VA), value linking (VL), value restructuring (VR), dan innovation valuation; (3) intangible benefit - manfaat tidak nyata atau yang dapat dilihat mempunyai dampak positif bagi instansi, tetapi tidak secara langsung berpengaruh pada keuntungan.Contohnya meningkatkan citra instansi, meningkatkan moral pegawai, dan sebagainya. Analisis terhadap intangible benefit menggunakan dua penilaian. Pertama adalah business domain. Komponen-komponen penilaian dari domain bisnis antara lain: strategic match, competitive advantage, management information support, competitive response. Penilaian kedua adalah Technology Domain. Komponen-komponen penilaian dari domain ini antara lain: strategic IS architecture, defitional uncertainty, technical uncertainty, dan infrastructure risk.

Kategori manfaat 1 (tangible) dan 2 (quasi tangible) menggunakan pendekatan financial enhanced ROI, di mana hasil penilaiannya menghasilkan suatu nilai moneter dan skor angka sedangkan kategori manfaat ke-3 menggunakan pendekatan non-finansial (domain bisnis dan teknologi), di mana hasil penilaiannya adalah sebuah skor angka. Pada kategori ke-3 ini, skor berkisar dari 0-5. Dengan demikian, nilai proyek SI/TI diukur dengan formula berikut ini (Parker, 1988):

\section{Skor Proyek = Enhanched ROI + bobot bidang bisnis + bobot bidang teknologi Enhanced ROI = Traditional ROI + value linking + value acceleration + value restructuring+innovation valuation}

Untuk penilaian kelayakan suatu aplikasi, berikut ini kerangka kerja (framework) yang telah dibuat oleh Dr.Ir Benny Ranti, Msc sesuai dengan Information Economics (Gambar 1):

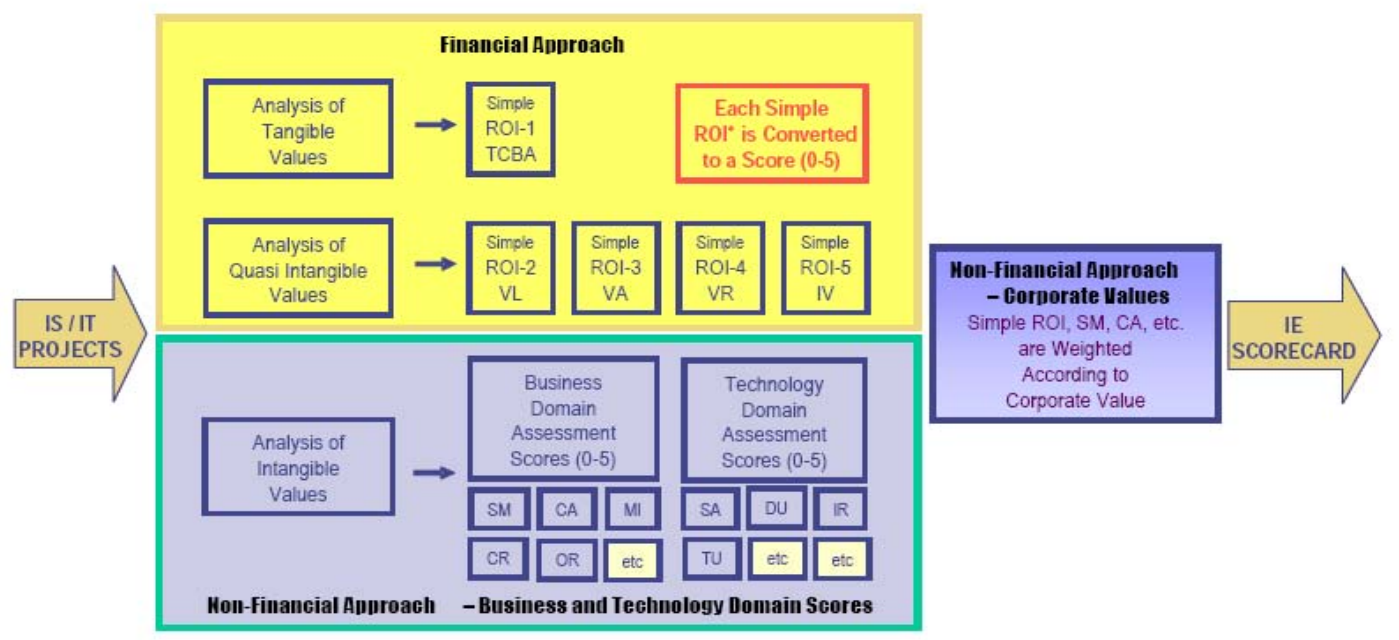

Gambar 1 Kerangka kerja information economics 
Kerangka kerja Information Economics tersebut sudah disusun sedemikian rupa sesuai dengan penjelasan sebelumnya pada bagian landasan teori Information Economics, dengan delivery yang didapat, yaitu IE Scorecard.

\section{Generic IS/IT Business Values}

Untuk mempermudah perhitungan ROI (Return Of Investment), digunakan generic IS/IT business values yang terdiri dari 13 kategori dengan total sub kategori sampai saat ini yaitu sebanyak 73 sub kategori (Table 1). Maka dengan menggunakan generic IS/IT Business Values ini, perhitungan Enhanced ROI tidak perlu dilakukan lagi.

Tabel 1 Generic IS/IT Business Values

\begin{tabular}{|l|l|c|c|}
\hline No. & Category & Code & $\begin{array}{c}\text { \# of } \\
\text { subcategory }\end{array}$ \\
\hline 1 & Reducing Cost & RCO & 15 \\
\hline 2 & Increasing Productivity & IPR & 4 \\
\hline 3 & Accelerating Process & APR & 8 \\
\hline 4 & Reducing Risk & RRI & 12 \\
\hline 5 & Increasing Revenue & IRE & 5 \\
\hline 6 & Increasing Accuracy & IAC & 5 \\
\hline 7 & Accelerating Billing Dispatching & ACI & 1 \\
\hline 8 & Increasing External Services & IES & 5 \\
\hline 9 & Increasing Image & IIM & 4 \\
\hline 10 & Increasing Quality & IQU & 4 \\
\hline 11 & Increasing Internal Services & IIS & 4 \\
\hline 12 & Increasing Competitive Advantage & ICA & 3 \\
\hline 13 & Avoiding Cost & ACO & 3 \\
\hline
\end{tabular}

\section{HASIL DAN PEMBAHASAN}

Analisis dengan menggunakan pendekatan finansial ini digunakan untuk mendapatkan ROI (Return of Investment) dari Aplikasi DSS pada CUKKyang dihasilkan. Analisis Generic IS/IT Values (Tabel 2) digunakan untuk mencari manfaat dari Aplikasi DSS pada CUKK, jika aplikasi tersebut diimplementasikan. Kemudian kuantifikasi (Tabel 3) dilakukan jika terdapat IS/IT Value yang memiliki dampak yang signifikan terhadap internal maupun eksternal organisasi

Tabel 2 Analisis Generic IS/IT Values

\begin{tabular}{cllcll}
\hline No & Generic IS/IT Business Value & Ya & Tidak & $\begin{array}{c}\text { Keterangan(Dengan } \\
\text { Adanya } \\
\text { AplikasiDSS) }\end{array}$ & $\begin{array}{c}\text { Perhitungan } \\
\text { (Kuantifikasi) }\end{array}$ \\
\hline 1 & Mengurangi Biaya & $\begin{array}{l}\text { Telecommunication Cost of } \\
\text { Certain Activities }\end{array}$ & $\checkmark$ & & \\
\hline 2 & Traveling Cost & & $\checkmark$ & & \\
\hline 3 & Staff/operator/employee cost & & $\begin{array}{l}\text { Dengan adanya } \\
\text { CUCIS tidak perlu } \\
\text { merekrut staf terlalu } \\
\text { banyak untuk bagian } \\
\text { administrasi }\end{array}$ & $\begin{array}{c}55 \text { kantorx1.800.000 } \\
99 \text { juta }\end{array}$ \\
\hline 4 & Meeting Cost & & & & \\
\hline
\end{tabular}




\begin{tabular}{|c|c|c|c|c|c|}
\hline 5 & Service Failure Cost & & $\checkmark$ & & \\
\hline 6 & Delivery Cost & & $\checkmark$ & & \\
\hline 7 & Training Cost per Employer & & $\checkmark$ & & \\
\hline 8 & $\begin{array}{l}\text { Returning Cost for Incorrect } \\
\text { Delivery }\end{array}$ & & $\checkmark$ & & \\
\hline 9 & Cost of Money & & $\checkmark$ & & \\
\hline 10 & Office Supplies and Printing Cost & & $\checkmark$ & & \\
\hline 11 & $\begin{array}{l}\text { Subcription cost of Certain } \\
\text { Reading Materials or Subscription } \\
\text { cost per Employee }\end{array}$ & & $\checkmark$ & & \\
\hline 12 & Space Rental Cost & & $\checkmark$ & & \\
\hline 13 & Device Rental Cost & & $\checkmark$ & & \\
\hline 14 & Inventory Cost & $\checkmark$ & & $\begin{array}{l}\text { Dengan ada nya } \\
\text { CUCIS biaya } \\
\text { inventory bisa di } \\
\text { minimalisir. }\end{array}$ & 90 juta \\
\hline 15 & Research Failure Cost & & $\checkmark$ & & \\
\hline II & Meningkatkan Produktivitas & & & & \\
\hline 16 & Restructuring Job Function & & $\checkmark$ & & \\
\hline 17 & $\begin{array}{l}\text { Accelerating Mastering Product } \\
\text { Knowledge }\end{array}$ & & $\checkmark$ & & \\
\hline 18 & Ease of Analysis & & $\checkmark$ & & \\
\hline 19 & Increasing Employee Satisfaction & & $\checkmark$ & & \\
\hline III & Mempercepat Proses & & & & \\
\hline 20 & Production Process & & $\checkmark$ & & \\
\hline 21 & Stock Procurement Process & $\checkmark$ & & $\begin{array}{l}\text { Dengan adanya } \\
\text { CUCIS sedikit } \\
\text { membantu untuk } \\
\text { membuat } \\
\text { perencanaan belanja } \\
\text { bulanan/tahunan } \\
\end{array}$ & 50 juta \\
\hline 22 & Reporting Making Process & $\checkmark$ & & $\begin{array}{l}\text { Dengan adanya } \\
\text { CUCIS sedikit } \\
\text { membantu untuk } \\
\text { membuat } \\
\text { perencanaan belanja }\end{array}$ & 30 juta \\
\hline 23 & $\begin{array}{l}\text { Data/information Preparation } \\
\text { Process }\end{array}$ & $\checkmark$ & & $\begin{array}{l}\text { Dengan adanya } \\
\text { CUCIS sedikit } \\
\text { membantu untuk } \\
\text { menyiapkan } \\
\text { perencanaan belanja }\end{array}$ & 15 juta \\
\hline 24 & Order Checking Process & & $\checkmark$ & & \\
\hline 25 & Debt Payment Process & & $\checkmark$ & & \\
\hline 26 & Transaction Process & $\checkmark$ & & $\begin{array}{l}\text { Dengan adanya } \\
\text { CUCIS sedikit } \\
\text { membantu untuk } \\
\text { memasukkan } \\
\text { beberapa transaksi } \\
\text { sekaligus ke dalam } \\
\text { system } \\
\end{array}$ & 120 juta \\
\hline 27 & Decision Making Process & $\checkmark$ & & $\begin{array}{l}\text { Dengan adanya } \\
\text { CUCIS sedikit } \\
\text { membantu dalam } \\
\text { proses pengambilan } \\
\text { keputusan }\end{array}$ & 20 juta \\
\hline IV & Mengurangi Resiko & & & & \\
\hline 28 & Risk of Price Miscalculation & $\checkmark$ & & Dengan adanya & 40 juta \\
\hline
\end{tabular}




\begin{tabular}{|c|c|c|c|c|c|}
\hline & & & & $\begin{array}{l}\text { CUCIS resiko } \\
\text { kesalahan bisa di } \\
\text { minimalisir } \\
\end{array}$ & \\
\hline 29 & Risk of Unrecoverable Claim & & $\checkmark$ & & \\
\hline 30 & Risk of Inventory Lost & & $\checkmark$ & & \\
\hline 31 & Risk Of Rejected Goods & & $\checkmark$ & & \\
\hline 32 & Risk of Data Lost & $\checkmark$ & & $\begin{array}{l}\text { Dengan adanya } \\
\text { CUCIS resiko } \\
\text { kehilangan data bisa } \\
\text { di minimalisir }\end{array}$ & 10 juta \\
\hline 33 & Risk of Incorrect Data & $\checkmark$ & & $\begin{array}{l}\text { Dengan adanya } \\
\text { CUCIS resiko } \\
\text { kesalahan data } \\
\text { berkurang }\end{array}$ & 10 juta \\
\hline 34 & Risk of Penalty & & $\checkmark$ & & \\
\hline 35 & Risk of Losing Potential Employee & & $\checkmark$ & & \\
\hline 36 & Risk of Forgery & & $\checkmark$ & & \\
\hline 37 & Risk of Administration Froud & & $\checkmark$ & & \\
\hline 38 & Risk of Incorrect Payment & & $\checkmark$ & & \\
\hline 39 & Risk of Asset Mismanagement & & $\checkmark$ & & \\
\hline $\mathbf{V}$ & Meningkatkan Pendapatan & & & & \\
\hline 40 & Increasing Business Capacity & & $\checkmark$ & & \\
\hline 41 & Increasing Report Quality & $\checkmark$ & & $\begin{array}{l}\text { Dengan adanya } \\
\text { CUCIS dapat } \\
\text { meningkat kan } \\
\text { kulaitas laporan }\end{array}$ & 10 juta \\
\hline 42 & Increasing Customer Trust & & $\checkmark$ & & \\
\hline 43 & Widening Market Segment & & $\checkmark$ & & \\
\hline 44 & Increasing Other Incomes & & $\checkmark$ & & \\
\hline VI & Meningkatkan Akurasi & & & & \\
\hline 45 & Increasing Billing Accuracy & & $\checkmark$ & & \\
\hline 46 & Increasing Analysis Accuracy & & $\checkmark$ & & \\
\hline 47 & Increasing Data Accuracy & $\checkmark$ & & $\begin{array}{l}\text { Dengan adanya } \\
\text { CUCIS akurasi data } \\
\text { nya semakin baik }\end{array}$ & 10 juta \\
\hline 48 & Increasing Planning Accuracy & & $\checkmark$ & & \\
\hline 49 & Increasing Decision Accuracy & & $\checkmark$ & & \\
\hline VII & $\begin{array}{l}\text { Percepatan Pengiriman } \\
\text { Penagihan }\end{array}$ & & & & \\
\hline 50 & Accelerating Billing Dispatching & $\checkmark$ & & $\begin{array}{l}\text { Dengan adanya } \\
\text { CUCIS setiap } \\
\text { peminjam yang } \\
\text { sudah memasuki } \\
\text { tanggal jatuh tempo } \\
\text { nya,bisa di lihat } \\
\text { melalui system. }\end{array}$ & 80 juta \\
\hline VIII & Peningkatan Layanan Eksternal & & & & \\
\hline 51 & Reducting Order Cancellation & & $\checkmark$ & & \\
\hline 52 & Knowing Customer's Problems & & $\checkmark$ & & \\
\hline 53 & Adding Point of Services & & $\checkmark$ & & \\
\hline 54 & Increasing Personalized Service & & $\checkmark$ & & \\
\hline 55 & Increasing Customer Satisfaction & & $\checkmark$ & & \\
\hline IX & Meningkatkan Brand & & & & \\
\hline 56 & Increasing Service Quality & $\checkmark$ & & $\begin{array}{l}\text { Dengan adanya } \\
\text { CUCIS kualitas } \\
\text { pelayanan terhadap }\end{array}$ & 30 juta \\
\hline
\end{tabular}




\begin{tabular}{|c|c|c|c|c|c|}
\hline & & & & $\begin{array}{l}\text { anggota semakin } \\
\text { baik }\end{array}$ & \\
\hline 57 & Offering Substantial Discount & & $\checkmark$ & & \\
\hline 58 & Complying With Regulations & & $\checkmark$ & & \\
\hline 59 & Using Branded Systems & & $\checkmark$ & & - \\
\hline $\mathbf{X}$ & Peningkatan Kualitas & & & & \\
\hline 60 & Increasing Raw Material Quality & & $\checkmark$ & & - \\
\hline 61 & Increasing Work Result Quality & $\checkmark$ & & $\begin{array}{l}\text { Dengan adanya } \\
\text { CUCIS kualitas kerja } \\
\text { menjadi cepat,akurat } \\
\text { dan memuaskan }\end{array}$ & - \\
\hline 62 & Increasing Service Quality & $\checkmark$ & & $\begin{array}{l}\text { Dengan adanya } \\
\text { CUCIS pelayanan } \\
\text { terhadap anggota } \\
\text { semakin cepat }\end{array}$ & - \\
\hline 63 & Increasing Product Quality & & $\checkmark$ & & - \\
\hline XI & Peningkatan Layanan Internal & & & & \\
\hline 64 & Shared Service & & $\checkmark$ & & - \\
\hline 65 & $\begin{array}{l}\text { Matching Employee's Right and } \\
\text { Responsibility }\end{array}$ & & $\checkmark$ & & - \\
\hline 66 & Employee Service & $\checkmark$ & & $\begin{array}{l}\text { Dengan adanya } \\
\text { CUCIS pelayanan } \\
\text { terhadap anggota } \\
\text { semakin cepat }\end{array}$ & - \\
\hline 67 & $\begin{array}{l}\text { Proper Schedule and Training } \\
\text { Material }\end{array}$ & & $\checkmark$ & & - \\
\hline XII & $\begin{array}{l}\text { Meningkatkan Keunggulan } \\
\text { Kompetitif }\end{array}$ & & & & \\
\hline 68 & Forming Business Alliance & & $\checkmark$ & & - \\
\hline 69 & $\begin{array}{l}\text { Accelerating the Execution of New } \\
\text { Business Opportunity }\end{array}$ & & $\checkmark$ & & - \\
\hline 70 & Increasing Switching Cost & & $\checkmark$ & & - \\
\hline XIII & Menghindari Biaya & & & & \\
\hline 71 & Reserved Fund & & $\checkmark$ & & - \\
\hline 72 & Maitenance Cost & & $\checkmark$ & & - \\
\hline 73 & Lost and Delay Costs & & $\checkmark$ & & - \\
\hline
\end{tabular}

Tabel 3 Kuantifikasi Berdasarkan Generic IS/IT Business Values

\begin{tabular}{|c|c|c|c|c|}
\hline \multirow[b]{2}{*}{ No } & \multirow[b]{2}{*}{ Kategori-Sub kategori } & \multirow[b]{2}{*}{ Rumus Kuantifikasi } & \multicolumn{2}{|c|}{ Perhitungan dengan asumsi (Kuantifikasi) } \\
\hline & & & $\begin{array}{c}\text { Sebelum adanya } \\
\text { aplikasi DSS }\end{array}$ & $\begin{array}{c}\text { Setelah adanya } \\
\text { aplikasi DSS }\end{array}$ \\
\hline 1. & $\begin{array}{l}\text { MENGURANGI BIAYA } \\
\text { Staff/operator/employee } \\
\text { cost }\end{array}$ & $\begin{array}{l}\text { Dengan adanya CUCIS } \\
\text { tidak perlu merekrut staf } \\
\text { terlalu banyak untuk } \\
\text { bagian administrasi }\end{array}$ & $\begin{array}{c}\text { *55 kantor } x \\
\text { Rp1.800.000= Rp99 } \\
\text { juta }\end{array}$ & $\begin{array}{l}\text { Setelah adanya aplikasi } \\
\text { DSS, biaya tersebut } \\
\text { dapat dihilangkan }\end{array}$ \\
\hline 2. & $\begin{array}{l}\text { MENGURANGI BIAYA } \\
\text { Inventory Cost }\end{array}$ & $\begin{array}{l}\text { Dengan ada nya CUCIS } \\
\text { biaya inventory bisa di } \\
\text { minimalisir. }\end{array}$ & Rp90 juta & $\begin{array}{l}\text { Setelah adanya aplikasi } \\
\text { DSS, biaya tersebut } \\
\text { dapat diminimalisir }\end{array}$ \\
\hline 3. & $\begin{array}{l}\text { MEMPERCEPAT } \\
\text { PROSES } \\
\text { Stock Procurement } \\
\text { Process }\end{array}$ & $\begin{array}{l}\text { Dengan adanya CUCIS } \\
\text { sedikit membantu untuk } \\
\text { membuat perencanaan } \\
\text { belanja bulanan/tahunan }\end{array}$ & Rp50 juta & $\begin{array}{l}\text { Setelah adanya aplikasi } \\
\text { DSS, biaya tersebut } \\
\text { dapat dihilangkan }\end{array}$ \\
\hline 4. & $\begin{array}{l}\text { MEMPERCEPAT } \\
\text { PROSES }\end{array}$ & $\begin{array}{l}\text { Dengan adanya CUCIS } \\
\text { sedikit membantu untuk }\end{array}$ & Rp30 juta & $\begin{array}{l}\text { Setelah adanya aplikasi } \\
\text { DSS, biaya tersebut }\end{array}$ \\
\hline
\end{tabular}




\begin{tabular}{|c|c|c|c|c|}
\hline & $\begin{array}{l}\text { Reporting Making } \\
\text { Process }\end{array}$ & $\begin{array}{l}\text { membuat perencanaan } \\
\text { belanja }\end{array}$ & & dapat dihilangkan \\
\hline 5. & $\begin{array}{l}\text { MEMPERCEPAT } \\
\text { PROSES } \\
\text { Data/information } \\
\text { Preparation Process }\end{array}$ & $\begin{array}{l}\text { Dengan adanya CUCIS } \\
\text { sedikit membantu untuk } \\
\text { menyiapkan perencanaan } \\
\text { belanja }\end{array}$ & Rp15 juta & $\begin{array}{l}\text { Setelah adanya aplikasi } \\
\text { DSS, biaya tersebut } \\
\text { dapat dihilangkan }\end{array}$ \\
\hline 6. & $\begin{array}{l}\text { MEMPERCEPAT } \\
\text { PROSES } \\
\text { Transaction Process }\end{array}$ & $\begin{array}{l}\text { Dengan adanya CUCIS } \\
\text { sedikit membantu untuk } \\
\text { memasukkan beberapa } \\
\text { transaksi sekaligus ke } \\
\text { dalam sistem }\end{array}$ & Rp120 juta & $\begin{array}{l}\text { Setelah adanya aplikasi } \\
\text { DSS, biaya tersebut } \\
\text { dapat dihilangkan }\end{array}$ \\
\hline 7. & $\begin{array}{l}\text { MEMPERCEPAT } \\
\text { PROSES } \\
\text { Decision Making } \\
\text { Process }\end{array}$ & $\begin{array}{l}\text { Dengan adanya CUCIS } \\
\text { sedikit membantu dalam } \\
\text { proses pengambilan } \\
\text { keputusan }\end{array}$ & Rp20 juta & $\begin{array}{l}\text { Setelah adanya aplikasi } \\
\text { DSS, biaya tersebut } \\
\text { dapat dihilangkan }\end{array}$ \\
\hline 8. & $\begin{array}{l}\text { MENGURANGI } \\
\text { RESIKO } \\
\text { Risk of Price } \\
\text { Miscalculation }\end{array}$ & $\begin{array}{l}\text { Dengan adanya CUCIS } \\
\text { resiko kesalahan bisa di } \\
\text { minimalisir }\end{array}$ & Rp40 juta & $\begin{array}{l}\text { Setelah adanya aplikasi } \\
\text { DSS, biaya tersebut } \\
\text { dapat dihilangkan }\end{array}$ \\
\hline 9. & $\begin{array}{l}\text { MENGURANGI } \\
\text { RESIKO } \\
\text { Risk of Data Lost }\end{array}$ & $\begin{array}{l}\text { Dengan adanya CUCIS } \\
\text { resiko kehilangan data } \\
\text { bisa di minimalisir }\end{array}$ & Rp10 juta & $\begin{array}{l}\text { Setelah adanya aplikasi } \\
\text { DSS, biaya tersebut } \\
\text { dapat dihilangkan }\end{array}$ \\
\hline 10. & $\begin{array}{l}\text { MENGURANGI } \\
\text { RESIKO } \\
\text { Risk of Incorrect Data }\end{array}$ & $\begin{array}{l}\text { Dengan adanya CUCIS } \\
\text { resiko kesalahan data } \\
\text { berkurang }\end{array}$ & Rp10 juta & $\begin{array}{l}\text { Setelah adanya aplikasi } \\
\text { DSS, biaya tersebut } \\
\text { dapat dihilangkan }\end{array}$ \\
\hline 11. & $\begin{array}{l}\text { MENINGKATKAN } \\
\text { PENDAPATAN } \\
\text { Increasing Report } \\
\text { Quality }\end{array}$ & $\begin{array}{l}\text { Dengan adanya CUCIS } \\
\text { dapat meningkat kan } \\
\text { kulaitas laporan }\end{array}$ & Rp10 juta & $\begin{array}{l}\text { Setelah adanya aplikasi } \\
\text { DSS, biaya tersebut } \\
\text { dapat dihilangkan }\end{array}$ \\
\hline 12. & $\begin{array}{l}\text { MENINGKATKAN } \\
\text { AKURASI } \\
\text { Increasing Data } \\
\text { Accuracy }\end{array}$ & $\begin{array}{l}\text { Dengan adanya CUCIS } \\
\text { akurasi data nya semakin } \\
\text { baik }\end{array}$ & Rp10 juta & $\begin{array}{l}\text { Setelah adanya aplikasi } \\
\text { DSS, biaya tersebut } \\
\text { dapat dihilangkan }\end{array}$ \\
\hline 13. & $\begin{array}{l}\text { PERCEPATAN } \\
\text { PENGIRIMAN } \\
\text { PENAGIHAN } \\
\text { Accelerating Billing } \\
\text { Dispatching }\end{array}$ & $\begin{array}{l}\text { Dengan adanya CUCIS } \\
\text { setiap peminjam yang } \\
\text { sudah memasuki tanggal } \\
\text { jatuh tempo nya,bisa di } \\
\text { lihat melalui system. }\end{array}$ & Rp80 juta & $\begin{array}{l}\text { Setelah adanya aplikasi } \\
\text { DSS, biaya tersebut } \\
\text { dapat dihilangkan }\end{array}$ \\
\hline 14. & $\begin{array}{l}\text { MENINGKATKAN } \\
\text { BRAND } \\
\text { Increasing Service } \\
\text { Quality }\end{array}$ & $\begin{array}{l}\text { Dengan adanya CUCIS } \\
\text { kualitas pelayanan } \\
\text { terhadap anggota } \\
\text { semakin baik }\end{array}$ & Rp30 juta & $\begin{array}{l}\text { Setelah adanya aplikasi } \\
\text { DSS, biaya tersebut } \\
\text { dapat dihilangkan }\end{array}$ \\
\hline 15. & $\begin{array}{l}\text { PENINGKATAN } \\
\text { KUALITAS } \\
\text { Increasing Work Result } \\
\text { Quality }\end{array}$ & $\begin{array}{l}\text { Dengan adanya CUCIS } \\
\text { kualitas kerja menjadi } \\
\text { cepat,akurat dan } \\
\text { memuaskan }\end{array}$ & - & $\begin{array}{l}\text { Setelah adanya aplikasi } \\
\text { DSS, biaya tersebut } \\
\text { dapat dihilangkan }\end{array}$ \\
\hline 17. & $\begin{array}{l}\text { PENINGKATAN } \\
\text { KUALITAS } \\
\text { Increasing Service } \\
\text { Quality }\end{array}$ & $\begin{array}{l}\text { Dengan adanya CUCIS } \\
\text { pelayanan terhadap } \\
\text { anggota semakin cepat }\end{array}$ & - & $\begin{array}{l}\text { Setelah adanya aplikasi } \\
\text { DSS, biaya tersebut } \\
\text { dapat dihilangkan }\end{array}$ \\
\hline 18. & $\begin{array}{l}\text { PENINGKATAN } \\
\text { LAYANAN INTERNAL } \\
\text { Employee Service }\end{array}$ & $\begin{array}{l}\text { Dengan adanya CUCIS } \\
\text { pelayanan terhadap } \\
\text { anggota semakin cepat }\end{array}$ & - & $\begin{array}{l}\text { Setelah adanya aplikasi } \\
\text { DSS, biaya tersebut } \\
\text { dapat dihilangkan }\end{array}$ \\
\hline
\end{tabular}

*Aplikasi ini sudah disosialisasikan di seluruh kantor baik di kantor pusat maupun kantor cabang untuk terimplementasinya aplikasi DSS pada masing-masing kantor, total kantor yang harus mengimplementasikan aplikasi DSS ini adalah 55 kantor. 
Setelah dijumlahkan, total penghematan biaya dan revenue yang didapatkan dari generic IS/ITBusiness Value, yaitu sebesar Rp614.000.000.

Konversi hasil ROI Generic IS/IT Values menjadi skor adalah sebagai berikut (Table 4).

Tabel 4 Lembar Dampak Ekonomis Pengurangan Biaya Operasional

\begin{tabular}{|c|c|c|c|c|c|c|c|c|}
\hline \multicolumn{9}{|c|}{$\begin{array}{l}\text { LEMBAR DAMPAK EKONOMIS } \\
\text { PENGURANGAN BIAYA OPERASIONAL, data dikalikan (1.000.000) }\end{array}$} \\
\hline $\mathrm{A}$ & $\begin{array}{l}\text { Biaya } \\
\text { Investasi }\end{array}$ & \multicolumn{7}{|l|}{ Rp. 150} \\
\hline \multirow[t]{4}{*}{$\mathrm{B}$} & $\begin{array}{l}\text { Arus Kas } \\
\text { tahunan }\end{array}$ & Tahun I & Tahun II & Tahun III & Tahu & IV & Tahun V & Total \\
\hline & $\begin{array}{l}\text { Manfaat } \\
\text { ekonomi } \\
\text { bersih }\end{array}$ & 0 & 0 & 0 & 0 & & 0 & 0 \\
\hline & $\begin{array}{l}\text { Pengurang- } \\
\text { an biaya }\end{array}$ & Rp. 614 & Rp. 614 & Rp. 614 & Rp. 6 & & Rp. 614 & \\
\hline & $\begin{array}{l}\text { Arus kas } \\
\text { bersih }\end{array}$ & Rp. 614 & Rp. 614 & Rp. 614 & Rp. 6 & & Rp. 614 & Rp. 3.070 \\
\hline $\mathrm{C}$ & \multicolumn{3}{|c|}{ ROI (TOTAL/5)/A } & \multirow{2}{*}{\multicolumn{5}{|c|}{\begin{tabular}{l|l} 
SKOR & Simnlo POI
\end{tabular}}} \\
\hline \multirow[t]{7}{*}{$\mathrm{D}$} & \multirow{7}{*}{\multicolumn{2}{|c|}{ Skor Dampak Ekonomi }} & & & & & & \\
\hline & & & & & $\overline{0}$ & & $<=1 \%$ & \\
\hline & & & & & 1 & $1 \%$ & $\overline{s / d}$ & $299 \%$ \\
\hline & & & & & 2 & $300 \%$ & $\mathrm{~s} / \mathrm{d}$ & $499 \%$ \\
\hline & & & & & 3 & $500 \%$ & $\mathrm{~s} / \mathrm{d}$ & $699 \%$ \\
\hline & & & & & 4 & $700 \%$ & $\mathrm{~s} / \mathrm{d}$ & $899 \%$ \\
\hline & & & & & 5 & & $>=900 \%$ & \\
\hline
\end{tabular}

Dari tabel 4 di atas didapatkan hasil sebesar 409,3\% dan termasuk 300\% s/d 499\% , sehingga skor yang untuk dampak ekonomis pengurangan biaya operasional adalah 2.

\section{PENUTUP}

Perhitungan persentase dari ROI mendapatkan hasil yang tinggi, yaitu sebesar 409,3\%. Sehingga dapat diperlihatkan bahwa Aplikasi DSS pada CUKK ini sangat penting untuk dijadikan perhatian.

Berdasarkan hasil penelitian yang telah dilakukan, penggunaan aplikasi CUCIS pada koperasi simpan pinjam adalah sangat baik. Dengan aplikasi ini dampak yang diperoleh dapat diukur dengan baik sehingga mendukung kinerja dari koperasi simpan pinjam itu sendiri. 


\section{DAFTAR PUSTAKA}

Laurensius, Ferry. (2004). Managemen kinerja sektor publik: mengatasi hambatan dalam siklus pengukuran kinerja. Jurnal Akuntansi \& Keuangan Sektor Publik, 2(2).

Parker, Marilyn, Robert J. Benson, H.E. (1988) .Trainor Information Economics: Linking Business Performance to Information Technology. New Jersey: Prentice Hall.

Turban, E. (2001). Decision Support Systems and Expert Systems and Intelligent Systems (6th edition). New Jersey: Prentice Hall. 